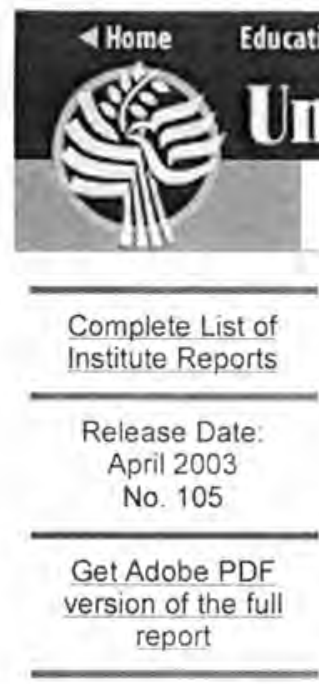

CONTENTS

Introduction

"Warlordism" and

Regionalism

Persistence of Warlords

Tackling Warlords

Ethnic Dynamics

Pashtun Sentiments

International

Community

Glimmers of Hope

Concluding Points

About the Report

Library Links

Of Related Interest

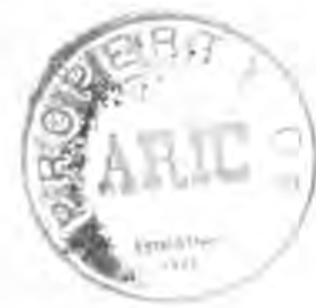

SPECIAL REPORT 105

\title{
Unfinished Business in Afghanistan
} Warlordism, Reconstruction, and Ethnic Harmony

\section{Briefly...}

- In comparison to the quick and successful U.S. military campaign to oust the Taliban, the political task of creating a stable and secure democratic state in Afghanistan is proving much more difficult. There are some hopeful signs since January 2003 with sections of President Hamid Karzai's government apparatus becoming more functional. But the central government continues to be severely hampered in the absence of adequate funds, security structures, and infrastructure.

- The most compelling challenges facing Afghanistan today are: legitimizing the central government and managing center-periphery relations, especially in dealing with warlords; providing credible security and rule of law extending beyond Kabul; economic reconstruction; and maintaining ethnic harmony and

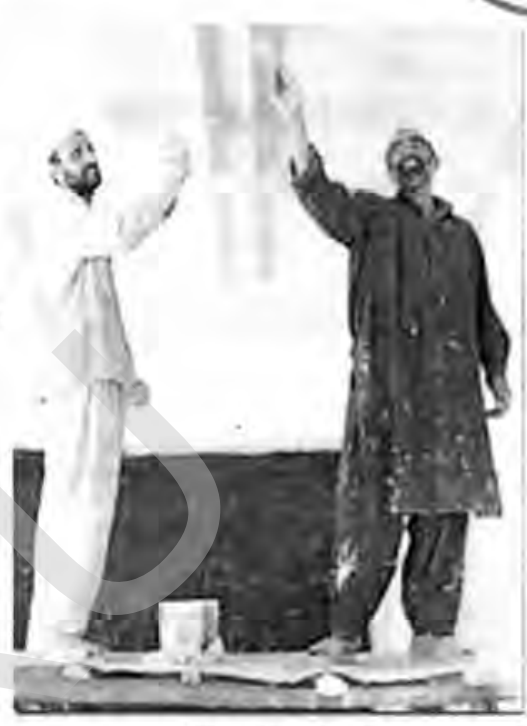

Courtesy USAID

Afghans paint the interior of the Sayeed Jamaludin Teacher's Training College in Kabul. The college was rebuilt with funding from USAID and implemented through the International Organization for Migration (IOM), in collaboration with the Transitional Government of Afghanistan. achieving national integration.

- The roots of "warlordism" are both internal and external. Historically, the Afghan central government has been weak, with regionalist politics the norm. Regionalism and warlordism are not the same, but warlords use regionalism for their own purposes when circumstances allow. The manner in which the United States fought the Soviet Union by furnishing weapons and money to a variety of Afghan commanders rather than to a centralized political authority facilitated warlordism. Similarly U.S. military strategy between $9 / 11$ and the establishment of the Karzai government emphasized support for those Afghan commanders capable of working with the United States in pursuing its military objective, thus contributing to the persistence of warlords.

- The lack of international security forces or an effective national army beyond Kabul leaves the provinces outside of international and central control, with warlords filling the vacuum. Regional actors question the government's capacity to provide basic public goods and undermine its authority by controlling alternative resources through a variety of mechanisms, including illegal transit fees, smuggling, and drug dealing. 
- The ethnic dynamics, while potentially volatile, continue to be reasonably well balanced. U.S. military action affected the political balance and tilted power away from the Pashtuns, who find this difficult to accept. But the Pashtun community also suffers internal divisions based on region. ideology, and leadership personality. The victory of religious (as opposed to nationalist) Pashtun parties in the October 2002 elections across the border in Pakistan raises concern about its implications for Afghanistan. U.S. intervention in Iraq may also mobilize Pashtun sentiment against American involvement in Afghanistan and increase attacks against U.S. troops.

- Afghanistan's future is going to be significantly determined by how much priority the country will receive in the short and medium run on the international community's agenda. So far, international assistance has tended to be long on promises, short on delivery. This undercuts U.S credibility in particular since the United States is seen as President Karzai's strongest ally. Unless international attention can be maintained on peace and reconstruction in Afghanistan even as other issues threaten to overwhelm the international agenda, there is a danger that while the battle has been won, the war will be lost. The flare-ups between U.S troops and remnants of the Taliban or al Qaeda fighters since late January 2003 serve as a sharp reminder that Afghanistan remains at risk.

\section{[Back to top ] \\ Introduction \\ Should the situation in Afghanistan be viewed as a glass half empty or a glass half full? The participants who attended the three Afghanistan Working Group meetings held at the Institute between November 2002 and January 2003 gave different answers to this question, but there was consensus that much work remains to be done in Afghanistan to keep it from sliding downwards. Afghanistan is not out of the woods yet because it is plagued by multiple challenges at the domestic, regional, and international levels. The sense was that the scale of the problem of reconstruction is much larger than most analysts had anticipated. For example, more than a year after Hamid Karzai was installed as president, the central government's control remains highly tenuous beyond the outskirts of Kabul-some close observers claim that up to 75 percent of the country is controlled by warlords and regional leaders. At the same time, the remarkable resilience of the war-weary population and their commitment for change from the past serves as a strong base for charting a new course. There is popular expectation that the United States-having removed the Taliban from power-will lead a major reconstruction effort by the international community.}

Many participants pointed out that Afghanistan is one of the world's poorest countries (fifth in the world), ravaged by more than two decades of war and strife. and that it would be foolhardy to expect change overnight, In 2003, Afghanistan remains the world's largest exporter of heroin, ensuring a debilitating connection between criminal elements and warlords. Apart from the huge economic devastation, Karzai's government also inherited dysfunctional political and bureaucratic institutions from the Taliban era and previous regimes, which have to be revamped. As important, Kabul does not control tax revenues (especially customs duties), which remain in the hands of regional power brokers. A lingering question is whether the international community, especially the United States, can marshal the necessary resources and political staying power to assist President Karzai even as the crisis in Iraq unfolds

The immediate challenges are manifold: legitimization of the central government and managing center-periphery relations, especially warlords; provision of credible security and rule of law beyond Kabul; maintaining ethnic harmony and achieving 
national integration; and ensuring that the international community delivers on its promises. These are the key issues that were taken up by the speakers and discussed by the participants in the Afghanistan Working Group. Barnett Rubin. New York University, Thomas Barfield, Boston University, and Larry Sampler. Institute consultant, made brief presentations on "Warlordism and Regionalism in Afghanistan": Samina Ahmed, International Crisis Group in Pakistan, gave a talk on "Post-Taliban Ethnic Dynamics"; and Robert Finn, U.S. ambassador to Afghanistan, led discussions on "Afghanistan Today."

\section{[ Back to top ]}

\section{"Warlordism" and Regionalism in Afghanistan}

The term "warlord" is now a contested term, but for our purposes it denotes an individual who exercises a combination of military, political, and economic power outside a constitutional or legal framework. Warlords are particularly threatening when they exercise power over distinct geographical regions. In normal, bureaucratically organized and functioning states, the government defines the legitimate sub-national territorial units over which power is to be exercised. In Afghanistan, these units consist of 32 provinces (up from 29 in 1978), but there are also hauzas, military zones the communist regime created in the 1980 s By and large, the regionally based warlords operate within the hauzas. This form of regionalism is not unique to Afghanistan, and is in fact a form of politics in parts of post-Soviet Central Asia. However, how did a combination of warlordism and regionalism emerge in today's Afghanistan? There is some social basis for it, but one determining factor is whether sufficient resources are available for building a central state that can incorporate or subordinate those wielding regional military power. The Taliban successfully subordinated them with Pakistani and later al Qaeda assistance, one of the most popular things the Taliban did.

The re-emergence of warlords after the ouster of the Taliban is partly related to the U.S. decision to support regional commanders (who could help American military objectives) with money and weapons during the campaign after September 11 rather than supporting a central authority. This approach resembled the war waged by the United States against the Soviets in the 1980 s, but one participant emphasized that it was Pakistan's Inter-Services Intelligence (ISI) that was America's key conduit to the warlords during that period, thereby allowing the ISI to select recipients that served its own interests without any thought of strengthening Afghanistan's central government. This time around, some officials argued that the United States should delay the initiation of hostilities after September 11 until an international conference to legitimate an alternative Kabul government was held so that the United States did not need to rely on decentralized commanders, but their view did not prevail. Working group participants noted, however, that it is incorrect to believe that because these commanders re-emerged with U S assistance, Americans and their allies now can dictate terms to them.

\section{[Back to top ]}

\section{The Persistence of Warlords}

The warlords persist because the conditions that allow them to remain have not fundamentally changed. Besides, they have a strong incentive to retain power as long as possible. It is no accident that the major customs posts of Herat, Kandahar, Jalalabad, and Balhk (near Mazar-i-Sharif), which produce considerable revenue, fall under their control. The goods that pass through these customs posts are primarily smuggled goods, such as consumer durables from the Persian Gulf headed for the smugglers' markets in Pakistan, and now increasingly for the Afghan market (largely for foreigners with hard currency). 
The factor that contributes most to the survival of warlords is the continuing weakness of the center vis-a-vis the periphery. Historically, Afghanistan's central government had the lowest rate of taxation per capita of any nation in the world. and it tended to obtain resources externally, including transit fees, "supervised smuggling," or international aid. The central government's trump card has been that it has a monopoly on outside resources. After the Taliban was expelled, all the regional commanders realized that a key source of power for the central government would be international aid, something which the average warlord had no access to. The lack of adequate outside funds to the government, however, has made the warlords question the government's capacity to provide basic public goods and given them the signal to develop their own alternative resources through illegal transit fees, smuggling, and drug dealing. There are also some who would like nothing better than to see the central government fail in its responsibilities, and actively seek to undermine the government's capacity. The lack of security structures beyond Kabul allows the warlords to consolidate their power without fear of being checked. There is neither a sufficient international security force outside the capital or a credible national army, leaving the provinces outside international and central control. Warlords fill the vacuum. There was a consensus among participants that the decision to restrict the International Security Assistance Force (ISAF) to Kabul has been a mistake. There is no international security presence outside Kabul that is not fighting a war or perceived as a combatant (largely U.S. forces).

The purpose of the Bonn Agreement (resulting from the Bonn conference convened by the United States and other key international actors in December 2001, which brought together many of Afghanistan's warring or competing groups) is to establish a national government, modeled on the 1964 Constitution, which in administrative terms means a centralized administration. The 1964 Constitution was selected because it was the best legal framework available and the one with the greatest legitimacy among Afghans. It is fair to say that most people who are not leaders of armed groups welcome a strong central government, which in people's minds is equated with provision of security and rule of law. In that respect, the Taliban government received considerable public support. When decentralization or federalism is brought up, many people in Afghanistan interpret it to mean that regional commanders and warlords can keep their militias. The basic dilemma in setting up the Afghan political entity is that "you have to organize some state power before you can decentralize it." In Bosnia, to cite a recent experiment, the negative consequences of decentralizing before consolidating the central authority continue to slow peacebuilding.

\section{[Back to top ]}

\section{Tackling Warlords: Combat or Co-opt?}

Opinion among the participants was split about the best way to deal with the warlords - whether to combat them or try to co-opt them. One of the more provocative views put forth was that the warlords should not be dislodged unless there was something to replace them with. Warlords are a problem, this participant said, but in some cases, especially in the rural areas, they provide the only stability. An analogy was made to the situation in Bosnia, especially the relationship between the Federation and the Republika Srpska to the government of Bosnia and Herzegovina. From this perspective, warlords emerged in direct response to the absence of law and order, and the argument for an immediate military strategy to oust them is off the mark. Examples were given of Afghans who lament the current security situation, and note that at least under the Taliban. they could the take their produce to the market, herd their goats, and go about their daily business. According to this observer, "the warlords need to see a way out, If they are painted into a corner and their choice is between a cell at the Hague and continued warlordism, they are going to choose warlordism. "Another observer noted with some irony that the Taliban successfully filled the "security 
vacuum," which meant that staff from nongovernmental organizations (NGOs) could operate without undue concerns regarding their safety, unlike the current situation.

A participant who disagreed with this view offered a counterargument: there is short-term satisfaction, but a long-term cost in financing and working with individuals like Ismail Khan and General Abdol Rashid Dostom. The idea of working with them just because they are "convenient" needs to be given up. The best way to handle the warlords is to make sure that international resources are swiftly channeled through the Kabul authorities. Another participant also took issue with the notion that "you can be a war criminal and still have a place in governing the country." But another person argued that the situation was more complex than that: for the last 20 years, "everybody who was exercising power was a war criminal in one way or the other because there wasn't any other way to exercise power."

What is necessary, then, is a process that will connect human rights and accountability issues with institution building and the future of Afghanistan. Participants agreed with this view, but no one saw such a development on the horizon. (The Rule of Law Program at the U.S. Institute of Peace is deeply involved in working with Afghan jurists and legal scholars on transitional justice issues and creation of a functioning judiciary system in Afghanistan, as well as on crafting a new constitution. The program sponsored a "Symposium on Afghanistan and the Rule of Law," February 2-4, 2003, that brought together a cross-section of Afghan legal officials and international experts to explore options to reform and rebuild Afghanistan's justice system. The Afghan participants recommended the establishment of an inter-ministerial working group that will meet twice a month in Kabul to facilitate collaboration between the different components of the Afghan justice system.)

Within Afghanistan there seems to be a disconnect between the time schedule set up for establishing legal authority, and the situation on the ground. For example, it is said that warlords have no place in the process because they do not exist in the chain of command, and that the provincial governors are in charge. In reality the governors have often been "selected" by the regional commanders and the latter see the governmental process as largely "window dressing." Since warlords are not going to disappear in the immediate term, there was some suggestion that a distinction be made between those who are unreconstructed and militaristic versus those who are willing to see the future of Afghanistan through a political rather than a military lens - that is, those who want to make a transition "from warlord to ward leader." This means that the warlords need to be brought into the process if only to figure out how to eliminate them, how to rehabilitate them, or how to identify a new generation of leaders in the provinces who may be "junior warlords" without the baggage of their predecessors.

In this view, it is important that the international community also deal with the subnational areas of the country, rather than exclusively with Kabul. The argument is that Afghanistan will never be able to achieve the kind of central government it had prior to 1978, and that the regions have over time deepened their identity and autonomy, which cannot be easily restricted. Thus some of the participants critiqued the conventional wisdom that the center needs to be significantly strengthened vis-a-vis the periphery. One of the participants believed that "the only reason that Afghanistan is still one territorial unit is that it never had an overbearing centralized state."

President Hamid Karzai himself seems to be of two minds on the best approach for dealing with the warlords-combat or co-opt-partly because the government is divided on this issue, and partly because there are limits on what he can do to combat them. Apparently. Karzai began by welcoming the warlords into the political process at last year's Loya Jirga (grand council), hoping that including 
them would change their behavior. More recently, he has been taking a tougher line, saying that his government would no longer tolerate individuals persecuting the population in the name of the government. As early as the Bonn conference, people recognized the need to deal with warlordism. Annex I of the Bonn Agreement stipulates that all armed groups are to be incorporated into national armed forces, but then "reorganized," which actually means "demobilized," However, the language of demobilization could not be included in the agreement because it produced an outcry among the commanders in Afghanistan.

The process of substituting institutionalized security forces for the warlords is unlikely to be completed in time for the elections, scheduled for mid-2004. Without this transition, there is every likelihood that warlords and regional power brokers with access to money and influence may hijack the electoral process. This would be a big blow to building democratic institutions. Indeed, there is some evidence that the more extremist groups are organizing effectively for the elections. whereas the democratic forces appear weak and fragmented. Reports also indicate that the moderate groups are being subjected to harassment and intimidation by the intelligence services.

Several observers pointed out that the creation of the Afghan National Army (ANA) will be an arduous process, in part because of current military imbalances between the North and South, the enormous task of disarming local militias, and disagreements about the optimal size of the army. Regarding the size of the army. one participant noted, "the question is not what the state can sustain, but what can sustain the state?" The numbers being discussed initially ranged from 20,000 to 70,000 , with the international community apparently suggesting the former and Karzai's government envisioning the latter. A consensus on the latter figure was finally reached. While there is no agreement about how many armed men are outside the government currently, estimates are as high as 100,000 and as low as 30,000 . Even the lower figure is astonishingly high.

\section{[ Back to top]}

\section{Ethnic Dynamics: Striking the Right Balance}

One of the effects of the American military intervention has been to tilt the balance of ethno-political power away from the majority Pashtuns in Afghanistan. As one speaker pointed out, with the dislodging of the Taliban, most of whom were Pastun, it is effectively no longer a "Pashtun state." This has been difficult for the Pashtuns to accept. However, even when the Taliban was in power, a minority opinion held that Taliban rule could not last because the Pashtuns are not a homogenous community. The Pashtuns are divided internally, along regional, ideological, and leadership lines. Indeed, the Taliban was described as a "warring alliance"- -an alliance of ideologues at the center with tribal chiefs, traders, and other actors who perceived that their interests at that point in time lay in supporting the Taliban. Intra-Pashtun divisions continue now as in the past. For example, there are major differences between the East and South that impact Pashtun strategy. Had they been more united and arrived at a consensus about what they felt was their rightful role, Pashtuns might have been able to play a more pro-active role in the Bonn process than they did.

The question of who represents the Pashtuns keeps coming up but there is no simple answer, in part because the Afghans as a rule are divided along sectarian and regional lines, giving rise to divergent interests within any given ethnic community. Participants viewed this as not necessarily a negative situation, since the end result is a highly pluralistic society. According to one of the speakers, the critical factor is that every ethnic community must have a voice at the table, not whether each conclave faithfully represents the country's precise ethnic composition. The "numbers game" in a state like Afghanistan is not going to be very productive. 
Nonetheless, political reconstruction cannot take place without addressing the genuine concerns of the Pashtuns: concerns about security, participation, and representation. Pashtuns currently believe that other ethnic minorities have too much of a voice at the table, not because of their political standing within the country, but because of international support. The key to successful development, however, is to de-link representation and policy from the actual numbers-in other words, to avoid quotas, a mistake made in Bosnia. One observer noted that, while there were unrealistic expectations from the Loya Jirga, the process itself was flawed. A key drawback was the perception that decisions were "taken outside the tent, and not inside." This was exacerbated by the belief that even inside the tent, the process was not as transparent as it could have been. For example, the number of participants increased at the last minute and intelligence agents (largely from one community) were apparently allowed in, which led to considerable alienation among the Pashtuns as well as other groups including the Uzbeks and the Hazaras.

One sensitive issue revolves around whether to hold a census or not. Without a census, there are likely to be the same post-Loya Jirga battles over numbers. There is a belief that some regions were deliberately left out or underrepresented because they were Pashtun based. If a census is not undertaken, each community will try to inflate their numbers, with for example, Pashtuns arguing that they comprise up to "70 percent, whereas the Tajiks will counter that they make up 50 percent, and other ethnic groups disagreeing with both." The speaker thought that there was sufficient local capacity for conducting the survey and suggested that what is needed is international backing for a credible and neutral census.

\section{Pashtun Sentiments}

At the moment, the most critical concerns for Pashtuns are security and their view of themselves as "victims." In north and northwest Afghanistan, there have been reprisals and settling of scores as the Hazaras, the Uzbeks, and the Tajiks battle among themselves to control the territories that the Taliban once dominated. According to one speaker, the Pashtuns are the losers in this struggle. Internally displaced Pashtuns often leave those areas and bring tales of persecution with them, thereby adding fuel to the fire. The assassination of Vice President Haji Qadir, a Pashtun, left some in the Pashtun community wondering whether their leaders were being targeted to deprive them of a political role in Kabul. This speaker argued that such sentiments should not be allowed to fester, and that incidents of this type need to be dealt with without delay

Much of the assessment of Pashtun sentiments reported to the working group is derived from primary interviews conducted among the Pashtuns in both Afghanistan and the border areas of neighboring Pakistan by locally based researchers. It is interesting to note that one initial response to the survey was resistance to speak about ethnically based concerns. Individuals admonished the researchers that "this is not the time to talk about ethnic differences, about divided entities. ... This is the time to talk about a united Afghanistan." There was also concern that if they said anything "even remotely critical," it might be construed as opposition to the Bonn process, to the international community, and to the Karzai government, with the danger of being branded as either Taliban supporters or members of the terrorist group al Qaeda

Based on the opinion survey, the researchers concluded that at this stage, Pashtun grievances have not reached a point that threatens the political process currently underway. However, two developments outside the borders of Afghanistan could have a future impact: (1) the victory of religious parties in Pakistan, in the border areas of Baluchistan and Northwest Frontier Province: and 
(2) the Iraq crisis. Kabul has concerns about the effect of pro-Taliban elements in Pakistan on Afghanistan's internal stability, including the stability of the Karzai government. According to one expert, there is some evidence that cross-border manipulation by Pakistan east of Kandahar is generating unrest among Pashtuns. possibly increasing ill will with Ismail Khan's forces. Pakistani Pashtuns appear to have both economic and political interests in Afghanistan. Pashtun traders, both Pakistani and Afghan, believe that they have significantly lost out, postSeptember 11 and post-Taliban. The trading community plays an important role, economically and politically. In light of Afghanistan's land-locked status, the Taliban supported Pakistani, as much as Pashtun, trading interests. Still, the response of the trading community to the political change has been pragmatic, not wanting to destabilize the political process because they believe that destabilization will cost them even more, At the same time, they have made it clear that if they are discriminated against, they will look to alternative local support. One particpant suggested that while the Pashtun traders "are not spoilers, they can become spoilers."

Beyond their economic interests, Pakistani Pashtuns believe that fellow Pashtuns across the border have suffered and continue to suffer because of U.S. military action, with a strong accompanying sentiment that they must help Pashtuns in Afghanistan. Ironically, Pashtuns on the Afghan side are extremely suspicious of "anything that comes from across the border." They remember Pakistan's role in the creation of the Taliban and what it did to their community and view Pakistani intervention as "totally undesirable." One of the speakers described the Afghan Pashtuns as more moderate in religious terms. They tend to view Pakistan as intervening to destabilize the Afghan state, the "Pashtun state." In this perspective, there is no natural drive for cross-border Pashtun unity, at least from the Afghan side.

If Pashtun alienation increases inside Afghanistan, especially in the East, then Pashtuns will become more vulnerable to extremist religious parties, especially from Pakistan. According to one observer, there are two types of Pashtun parties in Pakistan-"nationalist" and "religious." The October 2002 elections in Pakistan brought to power for first time the religious Pashtun parties on the Afghan border. while the "secular" nationalists lost. The religious parties were able to gain unprecedented support mostly by rallying popular Islamist sentiments against U.S. intervention in Afghanistan and against Pakistan's role. Traditionally, the nationalist Pashtuns sided with the United States and backed the fall of the Taliban, which was viewed as essential in getting Afghanistan back to its earlier more "secular" identity. If the political situation in Afghanistan stabilizes and the Pashtuns believe they have a stake in the system (which at this point seems to be the case), it will make it much harder to exploit cross-border religious or ethnic sentiments. Within the refugee camps, the researchers found that many young people were frustrated and receptive to the more extremist leaders such as Gulbuddin Hekmatayar largely because other leaders were not perceived as sympathetic to their concerns. Under these circumstances, U.S military action in Iraq is likely to radicalize people's sentiments, especially in the Pashtun border regions, but even beyond.

\section{[Back to top ]}

\section{The International Community: Delivering on Its Promises}

There was a general consensus that the international community has been long on promises, short on delivery. There was little doubt among the participants that a significant gap exists between what was promised for Afghanistan at the key meeting of international donors held in March 2002 in Tokyo, and what has reached the country. (The international community pledged $\$ 4.5$ billion for reconstruction in Afghnistan over five years at Tokyo.) In the opinion of one of the speakers, outsiders have failed to grasp the political fallout from not providing the 
resources that President Karzai's government needs. One of the standard "excuses" that is heard at the international level is that the government has to acquire greater capacity before it can absorb external funds. A counterargument is that money is required to build greater capacity. This has resulted in a catch-22 in Afghanistan.

Only a small portion of the funds, 10-18 percent, have been channeled through the Afghan government, although that figure is contested by some. Recognizing that his government had to respond to the international community's concerns about capacity and accountability, Karzai has retained well-regarded international financial consultants to assist with financial management of the funds. The minister of finance, Ashraf Ghani (formerly with the World Bank), has set up the Afghan Assistance Coordination Agency (AACA), which was reported to be functioning quite well. In addition, the government has indicated that in light of its existing inability to implement projects at the necessary pace, it would provide funds to the private sector and NGOs to carry them out. Although the state would act more like a regulating agency, it would also build up its administrative capacity in the process. One of the speakers who has experienced reconstruction in the Balkans concluded that "the Afghans are better prepared to receive international assistance than the Bosnians or the Kosovars." Other observers did not share this view, however

Another speaker noted that the issue is not just the amount of money provided. but how it is spent. The U.S. government has provided the amount of money it pledged at Tokyo, but a close look shows that most of these funds ended up being for humanitarian assistance, not reconstruction. Participants in the Tokyo meeting agreed that humanitarian expenditure is not to be included in the assessments, only reconstruction spending. Funds for humanitarian aid tends to go to U.S.based NGOs and other international agencies. Working group participants noted that there is a certain amount of confusion regarding the terms "humanitarian assistance" and "reconstruction," and that it is extremely difficult to have a perfectly distinguishable classification. For example, rebuilding of some schools have been classified as "humanitarian." (This issue is taken up at length in a joint study being conducted by the U.S. Institute of Peace and RAND Corporation assessing civil-military cooperation in delivering humanitarian assistance to Afghanistan. The study is slated for completion in April 2003.)

This speaker went on to describe how donor countries, not surprisingly, pursue their own interests when choosing projects to support. For instance, donors often want to fund highly visible projects that "they can be photographed in front of." International donors also tend to be more politically attracted to issues such as elections and human rights, rather than the more mundane capacity building at the local level. The difficulty of raising money for a census is but one example Donor countries commonly have legislation that requires them to give the aid to their own national entities; the United States has money to bring Afghans to Washington for study groups and training, which ends up "taking people away from their own work, " in this speaker's opinion. Apparently, the Afghans are "deluged" with this kind of invitation from many countries. A participant echoed this view and declared, the U.S. Agency for International Development "will pay one million dollars worth of salary costs for Save the Children USA to run rural clinics in Afghanistan, But nobody will give the very capable minister of health one million dollars toward her salary line to pay the rural health workers of Afghanistan."

One general criticism against the international community voiced by several participants was the inadequate expansion of ISAF. A major impediment to reconstruction work repeatedly cited by external donors, particularly NGOs, has been the lack of security outside Kabul. None of the speakers saw a quick or easy solution to this problem, though one speaker was hopeful about the new U.S. concept of Joint Regional Teams (now evolved into Provisional Reconstruction Teams or PRTs) to be sprinkled in selected areas of Afghanistan, whereby the U.S. military would be engaged in an overall reconstruction effort. The idea is that 
the PRTs would provide some minimum level of security for aid workers and others outside Kabul in the absence of Afghan army forces. By the end of February, three PRTs had been established-in Gardez, Bamiyan, and Kunduz. In addition, current plans call for PRTs in Kandahar, Heart, and Mazar. [The Institute of Peace hosted a conference on civil-military cooperation on January 16, 2003 in conjunction with the Center for Humanitarian Cooperation ( $\mathrm{CHC}$ ), which gave extensive attention to the notion of PRTs. For a detailed discussion of PRTs from a variety of perspectives, see the summary of the conference proceedings at CHC's web site: www caoperationcenier oig.]

There were two kinds of responses to this new concept of PRTs by the participants. One response related to the perceived expansion of the military's role in reconstruction work. As a participant put it, "No matter how many times you say that the military is there to facilitate humanitarian assistance, people do not want to hear that; they get nervous about the blurring of lines." For a variety of reasons, it was suggested that the State Department and U.S. Agency for International Development (as well as the Karzai government) needed to "take ownership" of the reconstruction element of the PRTs. Apart from this question of "who would be in charge," a second concern revolved around the implications for aid workers. A fear is that "anyone who is associated with these PRTs in any way, shape, or form would be a legitimate target" for armed opposition groups. As long as the U.S. military continues to perform a combat role (unlike in the Balkans where American presence was in the form of peacekeepers), security for aid workers will be difficult to guarantee. One speaker characterized the existing situation in Afghanistan as a "negative peace," that is, the international-or more specifically the Americanmilitary is keeping the peace. It is clear that there are few Afghans who want to take on the United States or face retribution from the United States, despite Afghanistan's long history of "settling scores." It would be unfortunate if another round of settling scores were to take place internally once the international community leaves. A positive peace requires more than just the threat of force to maintain peace.

A related question for the international community is whether it has the political will and resources necessary to help Afghanistan make this transition. In other words. is the United States prepared to be involved in significant nation building in Afghanistan. There are some who believe that even now, U.S. policy in Afghanistan is driven by the Pentagon's objectives, and that the task of fashioning a stable and democratic government is of secondary importance. As one speaker put it, "Afghans have been badly burned in the past by the international community leaving. This puts the central government in a very vulnerable position because if it has nothing to show for its efforts; it is vulnerable to regional commanders and to dissident elements that want to see the whole process destroyed." Many participants questioned whether the U.S. government has learned the lessons of the past. One participant closely associated with the U.S. government's plans in Afghanistan noted the failure of the American political leadership to elevate the reconstruction effort to the level that would have allowed more bureaucratic innovation in the delivery of assistance (along the lines of mechanisms set up for Eastern Europe and the former Soviet Union over a decade ago). This participant suggested that government analysts did not necessarily underestimate the scale of the challenges in Afghanistan, rather that they "overestimated the political will of [U.S.] leaders to come up with adequate funds over a realistic period in an effective manner."

\section{[ Back to top ]}

\section{Glimmers of Hope}

Despite the multiple obstacles described during the working group meetings, there were glimmers of hope identified as well. One of the speakers enumerated a number of positive developments that were noticeable by the beginning of 2003 
Just during the last months of 2002 , sections of Karzai's government finally began operating effectively. U.S. government funds have helped to link Kabul with 11 other provinces by telephone for the first time. (The enormity of the task is illustrated by the fact that nearly 20 other provinces remain to be connected.) A national radio network has been established. The government has also set up small radio stations in the provinces to reach a wider audience. To address the abysmal lack of infrastructure, the United States has decided to rebuild the KabulKandahar road. Psychologically, this is an important indicator about U.S. commitment. Transport is integral to economic regeneration in Afghanistan, both in terms of trading and of serving as a transit route. This speaker believes that the customs revenues being siphoned off at the various border points by regional warlords are roughly equivalent to the entire national budget. If there was a national road system, tolls could be charged by the central government, recapturing lost revenue.

The most heartening factor, however, is the perception of a renewed spirit among the Afghan population. One of President Karzai's favorite mantras is that the people of Afghanistan are far ahead of the government in re-development efforts. For example, people are opening shops in spite of the lack of electricity or direct government assistance. West Kabul, which was completely deserted and utterly devastated as of spring 2002 is under very active reconstruction.

Another positive feature has been the continuing adherence of the Afghan people by and large, to an "Afghan identity" despite the past assaults on the country's society and polity. According to one participant, Karzai has been very effective in promoting a "national consciousness," even at the government level in the midst of huge political competition for power and influence. His strategy of slow consensus building and persuasion seems to be more or less working on the ethnic front. For example, the current minister of education apparently had to be "cajoled" to accept this post over the Interior Ministry in the interest of ethnic balance; however, in the national education plan formulated under the new minister of education, "there wasn't a whisper of any kind of ethnic bias." This participant also cited the case of Defense Minister General Muhammad Fahim. "the most powerful person in the country," who is now talking about the need to have a national army that is trained and responsible to the central government. whereas as recently as the fall of 2002 , he was promoting the idea of regional armies maintaining power in different parts of the country. These are signs that Afghanistan is moving closer to the creation of a larger neutral statist identity that may be superimposed on divisive factional allegiances.

\section{[ Back to top ]}

\section{Concluding Points and Priorities}

- Resolving the dilemma regarding the nature of the Afghan state. In the long run, building local capacity is the only answer to ensure a functioning government. Most working group members believed that Afghanistan required a strong central government at this stage in its historical development, but there were differing opinions on just how "strong" it should be, whether it should completely subordinate the regional leaders or collaborate with them, and whether the international community should favor the government in aid disbursements or channel the funds through NGOs or other agencies that may be speedier and perhaps more responsive to the international agenda.

- Making the Afghan state a model for the region. One important theme was that in the past the Afghan state tended to be so weak that it barely delivered anything in terms of social or public goods, and the state that the Taliban took over was an impoverished state. Under the current circumstances, there is the possibility of reconstructing the state such that 
it becomes a model for the whole region; for example, combining the devolution of power while retaining sufficient authority at the center to fulfill its responsibility to provide public goods. The precise direction the Afghan state will take is yet to be determined, but it could provide some valuable lessons for the other states in the region

- Overcoming the security gap. The lingering security gap between Kabul and the provinces is the most daunting hinderance to reconstruction and political development. The international community's unwillingness to seriously address this gap could derail the whole enterprise. New initiatives. such as the U.S. Provisional Reconstruction Teams may have built-in shortcomings in this regard (since the aid workers may be perceived as part of the military force and therefore targeted by opposition groups), even as the PRTs demonstrate some renewed commitment by the United States. Efforts on the security front have to avoid the trap of being too little, too late.

- Making the right tradeoffs. Given the huge institutional and economic failures in Afghanistan in the past the agenda of reconstruction is extremely crowded. There was some contention among working group participants about which issues should be accorded higher priority. For example, how high should prosecution of war crimes rank? Should the imperative of providing security subsume other possibly competing concerns such as human rights? In the view of one speaker, "When somebody is on the receiving end of violence, they do not want to wait until the state is reconstituted before this issue is addressed."

- Resisting the tendency to settle into the "business as usual" mode. Afghanistan finds itself caught in the cross-currents of crisis and opportunity at this historical juncture. Whether the Afghan leadership will be able to grasp this opportunity will be determined in no small part by the policies of the international community. And of course those policies will be affected by other attention-and resource-grabbing events such as war in Iraq. To the extent that the United States and others are diverted because of events in Iraq, the slower the process will be of restoring Afghanistan to the successful (as opposed to the failed) state category. If in the future, there is a perception that the international community has failed Afghanistan-despite its commitment in Bonn and Tokyo-the damage to American credibility, especially with the Muslim world, will be great indeed

\title{
[Back to top ]
}

\begin{abstract}
About the Report
The Institute's Special Initiative on the Muslim World created an Afghanistan Working Group in November 2002 to provide a continuing forum to bring together leading practitioners, policy analysts, and academic and nongovernmental experts concerned broadly about Afghan reconstruction, regional politics, and international policy. This report is based on three off-the-record meetings of the working group held on November 1, 2002; November 26, 2002; and January 2, 2003. The discussion leaders were: Barnett Rubin. New York University, Thomas Barfield. Boston University, and Larry Sampler. Institute consultant, on "Combatting Warlordism and Regionalism in Afghanistan"; Samina Ahmed, International Crisis Group, Pakistan, on "Post-Taliban Ethnic Dynamics"; and Robert Finn, U.S. ambassador to Afghanistan, on "Afghanistan Today." This report follows Chatham House rules of reporting without attribution and was written by Deepa Ollapally. South Asia specialist, U.S. Institute of Peace.
\end{abstract}

The views expressed in this report do not necessarily reflect views of the United States Institute of Peace, which does not advocate specific policies. 
Unfinished Business in Afghanistan: Warlordism, Reconstruction, and Ethnic Harmon... Page 13 of 14

[ Back to top ]

\section{Institute Library Resources}

Afghanistan Web Links

www usip.org/library/regions/afghan.html

Iraq Web Links

www usip. org/library/regions/irag.htmi

[ Back to top ]

\section{Of Related Interest}

Many other publications from the United States Institute of Peace address issues that relate directly to conflict and peacebuilding in the Muslim world. Note: Most of our reports can be downloaded from our web site at www. usip.org/pubs.html.

\section{Recent Institute reports include:}

Establishing the Rule of Law in Irag (Special Report 104, April 2003)

After Saddam Hussein. Winning a Peace if 11 Comes to War (Special Report 102, February 2003)

Buliding interrefigious Trust in a Climale of Fear. An Abrahaintc Trialogue (Special Report 99, February 2003)

Would anc Invasion of lraq Ee as Jus Wan? (Special Report 98, January 2003)

Islamic Extremists: How Do They Mobilize Support? (Special Report 89, July 2002)

Islamic Perspectives on Peace and Violence (Special Report 82, January 2002)

See our complete list of reparis.

Recent books from USIP Press include:

Interfaith Dialogue and Peacebuilding, edited by David Smock (2002)

Religious Perspectives on War Christian, Muslim, and Jewish Attitudes Toward Force (rev. ed.), by David Smock (2002)

Isiamic Activism and U.S. Foreign Policy, by Scott W. Hibbard and David Little (1997)

For book sales and order information, visit our catalog online, or call 800-8688064 (U.S. toll-free only) or 703-661-1590, or fax 703-661-1501.

See the complete U.S instute of Peace Press Catalog online.

[Back to top ] 
,Unfinished Business in Afghanistan: Warlordism, Reconstruction, and Ethnic Harmon... Page 14 of 14

See our complete list of reports.

Publications Homepage | Peacewatch | Reports | Order Free Publications

Complete Catalog | New Books | Drder Books

Institute Home | Education \& Training | Grants \& Fellowships | Policy Research | Library \& Links

Publications | News \& Media | About Us | Events | Resources | Jobs | Contact Us Site Map 
